\title{
WORK CONDITIONS IN AGROINDUSTRY. INDIGENOUS FEMALE FARMWORKERS IN NORTHWEST MEXICO
}

\author{
María DE LOURDES CAMARENA OJINAGA \\ Universidad Autónoma de Baja California \\ Ensenada/Baja California/ Mexico \\ lcamarena@uabc.edu.mx
}

\section{Guadalupe CONCEPCIÓN MARTÍNEZ VALDÉS \\ Universidad Autónoma de Baja California \\ Ensenada/ Baja California/ México \\ conmar@uabc.edu.mx}

\author{
María EVARISTA ARELLANO GARCÍA \\ Universidad Autónoma de Baja California \\ Ensenada/Baja California/ Mexico \\ evarista.arellano@uabc.edu.mx
}

\begin{abstract}
This article presents results from research conducted among migrant indigenous female farmworkers. We analyse social inequality by focusing on the work conditions imposed by agroindustries. Seen as a process, labour conditions articulate several factors, such as hiring practices and forms of payment linked to the restructuring of horticultural production, and fluctuations in demand from the North American market for these export products. Structural determinants regarding employment, precarious labour conditions and increased poverty, linked to the little value given to the labour of farmworkers, have resulted in the violation of labour rights on the basis of class, gender and
\end{abstract}


ethnicity. The place of study was an agricultural valley in the state of Baja California, located 300 kilometres south of the Mexico-United States border. For over forty years this region experienced considerable growth and the establishment of export agroindustries becoming consequently a pole of attraction for migrant farmworkers from southern Mexico. A qualitative methodology was utilized. Group interviews were conducted with sixty women. Our findings allow us to make evident the unequal social relations and practices that intensify the vulnerability of these women, placing them in marked disadvantage with respect to other social groups.

\section{Keywords}

Agricultural labour; indigenous female farmworkers; labour rights; policy and business interest; precarious labour conditions

\section{INTRODUCTION}

Globalization processes have fostered not only the weakening of state mechanisms to regulate and protect labour, but the increase in job precariousness as well. These conditions run contrary to the provisions of the International Labour Organization (ILO) whereby every individual has the right to "decent work", which is defined as "productive work under conditions of liberty, equality, security, and human dignity, in which their rights are protected, and adequate payment and social protection is provided." (OIT 1999, 4). In addition, the Millennium Development Goals as modified in 2008 emphasize the need to "achieve full and productive employment and decent work for all, including women and youth" (cited in Weller 2012, 83). But in spite of these international commitments, women in general and indigenous women in particular, continue to conform the most vulnerable sector of the population regarding labour conditions.

Indigenous women in Mexico are the sector of the female population accumulating the greatest disadvantages. Historically speaking, they have been discriminated and poverty stricken, which means fewer educational 
opportunities, and reduced access to health, work and minimal welfare standards. It is under this context that indigenous women enter into paid agricultural employment. With the development of the country's agroindustry, the number of women casual labourers has risen. Various studies document the feminization process of field work due, among other factors, to the flexibility of the female labour force. (Morett y Cosio 2004; Lara 2008, 2003, 2001; Garduño 2010).

Based on research carried out with indigenous women labourers in the Valley of San Quintin, in the state of Baja California, we set out to analyse labour conditions and stipulations imposed by agroindustries under the protection of the State's social policies, by which these women suffer a socially differentiated and unjust situation. Indigenous female labourers are not exempt from job precariousness. This is characterized by numerous shortcomings such as low wages, lack of job security, hiring irregularities, intermittent and unstable occupation, and varying number of hours worked each day (Bayón, 2006). Various factors intertwine in the process of increasing labour precariousness suffered by the women labourers in this region. These include changes in labour demand, the forms of hiring and payment of daily wages, tied to the restructuring, diversification, and technification of horticultural production in the region, as well as the fluctuating demand for vegetables from the United States market.

The Valley of San Quintín is located 300 kilometres south of the Mexico-United States border, on the Pacific coast, and covers four municipal delegations. During the past forty years it has undergone an important agricultural development due to the production of export vegetables and fruit and consequently, has become a pole of attraction for migrant field labourers. The intensification of commercial agriculture has increased the demand for labour, requirement that has been met precisely by migrant workers from the southeast of Mexico, especially Mixtecs, Triquis and Zapotecs. The context of the San Quintin region as dictated by the dynamics of migration and the complex process of the labourers' gradual settlement, as well as the fluctuations in labour demand, make it difficult to estimate the number day labourers working in the fields. 
This paper is organized in four sections. In the first, we describe living and working conditions of indigenous women labourers within the development of the agroindustry of this region. In the second section, we address the violation of human rights. In the third, we present the methodology and what we consider to be our most important findings, and in the final section, we present some concluding statements.

\section{LIVING AND WORKING CONDITIONS OF INDIGENOUS LABOURERS IN THE VALLEY OF SAN QUINTÍN}

According to Antonieta Barrón's $(2007,132)$ estimates, some 35, 000 labourers, female and male, are employed in the state of Baja California, in so far as this state occupies second place in Mexico's tomato and vegetable production. The Valley of San Quintin produces 90 percent of the country's strawberries and cucumber. 51.4 percent of the economically active population works in the fields (Velasco, Zlolniski y Coubes 2014, 105). For the past forty years, agroindustry has benefitted from the competitive edge that low wages paid to the indigenous work force gives them for export production. Because of the difficult conditions in their places of origin, these workers have been forced to migrate in search of work in the agricultural fields of northern Mexico (Massieau-Trigo 2004). According to Velasco, the agroexport sector of the Northwest is characterized by being a "highly segmented work market based on class, gender, ethnic, and age bracket asymmetries, as well as on different forms of job recruitment" $(2014,31)$. Job insecurity and instability both conditions and guarantees employers a docile and cheap labour force and allows industries greater flexibility in the organization of work (Lara 2001); they also have a reduced cost by not paying benefits to their workers. According to a report presented by the Secretary of Social Development, field labourers in the zones of attraction are considered vulnerable due to their living and work conditions, where the latter are characterized by work overload, intensive use of labour 
force, excessive working hours, discrimination, and lack of access to basic services (Secretaría de Desarrollo Social 2010).

In general, day labourers in México live under precarious economic conditions, which makes it difficult to satisfy their basic needs. In the region studied, housing consists of single rooms within the work camps or houses that migrant families have gradually built. In both types of dwellings, conditions are unsatisfactory. Some have been constructed out of scrap material, floors are not cemented, scarce or no ventilation, and almost all public services are absent. In essence, they live in an unhealthy environment conducive to the development of a variety of diseases. All too often, there is overcrowding: a family of six may be found living in a dwelling of one or two rooms which function as bedroom, kitchen, and living room. Bathrooms are located nearby and are collective (PDHBC 2003). Nevertheless, due to the mobilization of regional political groups and leaders of indigenous organizations, the conditions in the colonies have improved with the provision of basic services such as water supply, electricity, stores, and primary (Reding 2008).

The living situation of female workers is conditioned by their work conditions. Work rhythms both within and outside the home prevent them from leading a healthy life. The environmental conditions of agricultural work mean they are exposed to the sun, dust, heat, cold and, above all, agrochemicals. They rise early in order to catch the bus that takes them to the agricultural fields and they labour long days, without resting, having only 30 minutes for a lunch break. As women, they have double day, upon returning home from work, they perform domestic chores. Labour conditions and demands extol a price on their physical constitution and premature aging. In addition, low wages limit their access to adequate nutrition.

The need to work impedes most women from receiving formal education beyond the first few years of primary schooling. At the same time, there are educational gaps between the indigenous and nonindigenous population, particularly with regard to school performance and permanence and the acquisition of reading and writing skills. As to access, the locality's schools that provide the indigenous population with an education lack adequate physical infrastructure, equipment, and information and communication technology. 
Nonetheless, indigenous women whose own formal education is deficient, seek that their children receive a secondary and higher education.

Governmental programs directed at indigenous communities are not able to cover all needs, particularly those of the most vulnerable groups within, such as the elderly, single mothers, and recent immigrants. It is the community itself that carries out diverse solidarity activities towards the more vulnerable.

Many of the female workers leave their original communities, alone or with their families, because of the lack of work, and they migrant with the expectation of a job and a better quality of life, both for themselves and for their families. However, within their new context, the only possibility open to them is field work, even if this option means job instability, insufficient wages, lack of security, irregular hiring practices, and varying working hours. Women work from a very young age until an advanced age. This means that young women are kept from studying due to the urgency to earn money for their own survival and that of their families. As a result, their possibilities of aspiring to a better paid job are hampered and this contributes to the reinforcement of their situation of social exclusion.

Women labourers experiences conditions that place them at a greater disadvantage in comparison to their male counterparts: they perform heavy tasks, work a long day, receive lower wages, and have no one to look after their children. There are jobs that are assigned preferentially to men, such as fumigation, driving vehicles and supervision. Women work inside the nurseries and harvest those products that require delicate handling. Tasks are not only allocated on a sexual basis but there also is an ethnical division of work, for example, when a supervisory position is assigned to a woman preference is given to a non-indigenous woman.

\section{A WINDOW ONTO LABOUR RIGHTS}

A majority of labourers has no access to social security or social benefits. The absence of formal contracts signifies that the agricultural worker and his/her 
labour rights are unprotected, a situation that is conducive to augmented social vulnerability. For indigenous women, this means a lack of access and use of social security services, insofar as they are not incorporated into the regime. In a study carried out with 419 women in the region of San Quintin, it was discovered that only 27 percent were affiliated to the Instituto Mexicano del Seguro Social (Mexican Institute of Social Security). This condition is associated with the workers' lack of knowledge regarding the procedure to be followed in order to become affiliated (Mujeres en defensa de la mujer, A.C. 2015).

Employers' non-compliance of the current laws in Mexico governing labour and the absence of monitoring by government authorities favour the violation of women's labour rights. The ineffective inspection of work areas, on the one hand, and on the other, the women's ignorance regarding their rights heightens their labour vulnerability. Labour exploitation and insecurity are largely due to an employer's interest in the opportune and competitive placing of his products on the market, not in complying with labour law stipulations. According to Orozco and Ortiz (2013), the Mexican state's intervention on behalf of industry led to a generalized precariousness of labour. These authors sustain that labour criteria and practices applied since the eighties became endorsed and legitimized by the labour reform approved in 2015. This led to the consequential erosion of labour rights and the deterioration of the workers' living conditions, which has resulted in greater poverty, social inequity, and setbacks in human rights.

The State has the responsibility of ensuring that the Federal Law of Labour be abided. The 2nd Article of this law states that in all work relations dignified or decent labour should be promoted; discrimination on the basis of ethnic or national origin, gender, age, among others, should not exist; all workers shall have access to social security, perceive a remunerative wage, enjoy optimal security and hygiene conditions that avoid job risks (LFT, 2015). In spite of the stipulations, various research studies, including those effected by the National Commission of Human Rights, have noted that the Law is not fully observed. The Commission has indicated that labour authorities, on both local and federal levels, do not comply with labour regulations and, in some cases, have not identified all agricultural companies and do not have complete information on 
these or this information is outdated, all of which prevents the proper inspection of agricultural activities (CNDH, 2019). This results in the repeated violation of labour rights and hampers an efficient inspection that would allow the identification of those work centres that do not observe labour regulations in order to apply preventive measures.

In addition to the non-compliance by labour authorities, employers avoid their responsibilities by not observing the regulations governing labour conditions: they do not provide the workers with proper gear or equipment for their personal protection when handling fertilizers and pesticides, nor do they provide proper training to those who carry out these chores. Likewise, employers do not comply with the sufficient provision of drinking water to their field workers, nor with the installation of portable toilets in the fields.

Employers also infringe the law when they do not incorporate their employees into the Instituto Mexicano del Seguro (IMSS), a public, decentralized institution in charge of organizing and administering social security. According to Article 15 of the Law of Social Security, employers are under the obligation to register their business and their workers, to comply with retirement security and old age severance, among other obligations. It is important to stress that the majority of agricultural workers are hired as temporary or seasonal workers which means that they do not accumulate seniority in employment nor do they receive minimum benefits. It should also be pointed out that the workers have no knowledge of affiliation procedures.

\section{METHODOLOGY AND FINDINGS}

A qualitative methodology with group interviews was employed. Interviews were carried out in the four delegations that make up the Valley of San Quintin. The interviews were recorded, with previous authorization, and Atlas.ti was used to determine analytic categories. Criteria used to select those interviewed were that they be indigenous, spoke Spanish and were agricultural labourers. Sixty women participated, ranging in ages from 18 to 60 . 
Findings are grouped under two main headings, as shown in the following table.

Table 1. Presentation of findings by indicators

Source: Prepared by the authors on the basis of the interviews

\begin{tabular}{|l|l|}
\hline \multicolumn{1}{|c|}{ Labour conditions } & \multicolumn{1}{|c|}{ Labour risks } \\
\hline Long and heavy work days & Work related accidents \\
\hline Work instability & Exposure to intense heat and dust \\
\hline Low wages & Exposure to agrochemicals \\
\hline $\begin{array}{l}\text { Scarce incorporation of workers to } \\
\text { social security }\end{array}$ & $\begin{array}{l}\text { No training in the handling of } \\
\text { agrochemicals }\end{array}$ \\
\hline Work equipment not provided & Bad ventilation in the nurseries \\
\hline Disrespectful treatment & Insect and snake bites \\
\hline Ethnic and gender discrimination & \\
\hline Work abuse picking & \\
\hline Unhygienic portable toilets & \\
\hline Low quality drinking water & \\
\hline $\begin{array}{l}\text { Non-ergonomic positions } \\
\text { products }\end{array}$ & \\
\hline
\end{tabular}

The women interviewed describe their work days as lasting between 8 and 12 hours, with usually only one short lunch break at midday; the exigencies of work force the women to eat quickly, next to the furrows, which practically inhibits any kind of social communication among them. They are assigned 
strenuous activities, which force them to maintain a tilted position for hours on end, bent over and carrying out repetitive movements. Part of their tasks involves using shovels and hoes and carrying buckets with the produce they gather and which may weigh as much as 20 kilos. Many of the companies do not provide adequate protective equipment which means they must cover their faces with kerchiefs or bandanas. They also buy their own tools, such as scissors, blades and hoes. When they pick strawberries or other types of berries, the employers do not let them use gloves as their use could damage the product. Some of the women mentioned that the companies look after their produce more than they do after their workers. Although in some fields, the employers or supervisors supply drinking water, in others they do not.

As regards to job instability, the women interviewed stated that the majority of contracts are verbal and effected through intermediaries. The informality of this type of contract implies insecurity regarding job permanency as well as income instability. During the low-activity season, the women work only 3-4 days out of the week, which means less income. Although some of the women work only with one company, some rotate from field to field. As to wages, these fluctuate between 10 and 12 dollars a day; but during harvest season, payment is on a piece-work basis, measured by the number of 20-liter plastic buckets filled to the brim, when the fastest workers can earn up to 27 dollars during a 12-hour day of labour.

The interviewees commented that the majority of workers, both female and male, are not affiliated to the social security system, which means that they and their labour rights are unprotected. And insofar as they have no access to health institutions, they find themselves and their families in a position of vulnerability in the case of accidents or illness.

The women endure both gender discrimination and sexual harassment not only from their supervisors but from their fellow workers as well. The group of interviewees claimed they had been harassed by their supervisors but should they complain, they would suffer reprisals, such as being assigned more furrows, or were refused entry to the fields for several days. Their work is permeated by relations of power: mestizo-indian, supervisor-worker, manwoman, and this intensifies the already scarce possibilities they have of 
expressing their inconformity with their labour relations, be it because of their subordinate position or because of the lack of knowledge regarding their labour rights.

One of the risks women labourers are exposed to is temperature changes and dust which can cause dehydration and sunstroke. The interviewees mentioned that, in the summer, they have seen women vomit and faint because of the heat. When they begin work, there is moisture in the fields and this exposes them to constant humidity which permeates their clothing. Over time this can cause cramps, musculoskeletal pain, and allergies. Furthermore, because of the type of work they do, some activities are dangerous; several have suffered falls which ended in lacerations and fractures; handling blades and scissors has also ended in injuries. The type of work carried out exposes them to sprains, muscular pain in the back, neck, shoulders, and arms. They are also exposed to insect and snake bite. Their biggest risk is undoubtedly their exposure to agrochemicals, even if they themselves do not engage in fumigation chores. Yet because the women remain in the fields when fumigation is carried out, they are practically sprayed, although some commented that in some fields, they are warned to stand clear of the furrow to be sprayed. The effects on health as a result of the exposure to toxic chemical products range from skin irritation (dermatitis) to intoxication, and is potentially carcinogenic.

\section{FINAL CONSIDERATIONS}

This paper presents a panoramic view of the living and work conditions of indigenous women labourers in the Valley of San Quintín. These conditions are characterized by discrimination, lack of job opportunities, unequal access to goods and services and to workers's social security benefits.

The precariousness with which they live has an impact on their state of wellbeing, which in turn constrains them in achieving better living conditions. The working life of each one of these women cannot be understood without relating it to her family situation. The work relations that are created within the 
agroindustries penetrate and absorb the advantages of family solidarity, insofar as they benefit from customs such as the care of children by grandmothers or the eldest daughter of the family, making it possible for them, the mothers, to go to work.

The vulnerable situation of women labourers is related to low wages, uncertainty in job conservation, payment on piece work basis, asymmetrical contracting, and the omission of labour benefit payments. This in turn relates to the restructuring, diversification and technification of horticultural production in the region as well as to the fluctuation in the demand for vegetables in the United States market.

The conditions and particularities of agricultural employment are generated by the actual restructuring of labour which searches for flexibility and a labour force that is adaptable to the work processes of agroindustry. The debasement of indigenous women's labour is related to the social relations in which they are immersed, relations that are framed by gender, class and ethnicity, and that enable wage inequality. More than the workers's skills, it is the structural context and the institutional mechanisms that classify, prioritize, and value work on the basis of power relations, and which make up the foundation on which these asymmetries are established.

Our findings underline that being indigenous and female points to their invisibility before employers, as well as Mexican governmental institutions. Being indigenous and being a woman places them in a socially differentiated situation that reflects the inequitable work relations within the agroindustries of the Valley of San Quintín and the neglectful and negligent position of the Mexican state.

\section{REFERENCES}

- Barrón, Antonieta. 2007. Jornaleros migrantes. Cuántos son y dónde están". En Mujeres afectadas por el fenómeno migratorio en México. Una aproximación desde la perspectiva de género. México: Instituto Nacional de las Mujeres, pp. 131138. 
- Bayón, María Cristina. 2006. "Precariedad social en México y Argentina: tendencias, expresiones y trayectorias nacionales". Revista de la CEPAL, 88 (abril), pp.133-152.

- Comisión Nacional de los Derechos Humanos. 2019. "Síntesis de la recomendación general 36/2019 sobre la situación de la población jornalera indígena en México". Diario Oficial de la Federación https:/ / dof.gob.mx/nota_detalle.php?codigo=5566708\&fecha=29/07/2019 \&print $=$ true.

- Garduño, Everardo. (coord.). 2010. Caracterización socioeconómica y cultural de la mujer indígena en los valles de San Quintín y Maneadero de Baja California. México: Instituto Municipal de la Mujer, CDI, (Ensenada, B.C.), Universidad Autónoma de Baja California.

- Ley del Seguro Social. Diario Oficial de la Federación. http://www.imss.gob.mx/sites/all/statics/pdf/leyes/LSS.pdf.

- Lara, Sara. 2001. Análisis del Mercado de trabajo rural en México en un contexto de flexibilización. En Giarraca, N. (comp.) Una nueva ruralidad en América Latina. Argentina: CLASO. pp 363-382.

- Lara, Sara. 2003. "Violencia y Contrapoder: una ventana al mundo de las mujeres indígenas migrantes, en México". Revista Estudios Feministas, 11(02), pp. 381-397.

- Lara, Sara. 2008. ¿Es posible hablar de un trabajo decente en la agricultura moderno-empresarial en México?" El Cotidiano 23(147), pp.25-33.

- Ley Federal del Trabajo. Diario Oficial de la Federación. https://www.gob.mx/cms/uploads/attachment/file/156203/1044_Ley_F ederal_del_Trabajo.pdf.

- Massieu, Yolanda. 2004. "Impactos de la biotecnología en la producción de hortalizas en México". Aportes 9(26), pp. 41-63.

- Morett, Jesus y Cosío, Celsa. 2004. “Los jornaleros agrícolas de México. México: Universidad Autónoma de Chapingo", Editorial Diana.

- Mujeres en defensa de la mujer, A.C. 2015. Situación de la mujer trabajadora en San Quintín. México: Mujeres en defensa de la mujer, A.C 
- Oficina Internacional del Trabajo. 1999. Conferencia Internacional del Trabajo. Trabajo decente. https://www.ilo.org/public/libdoc/ilo/P/09651/09651\%28199987\%29.pdf (consultado el 18/10/2019).

- Procuraduría de los Derechos Humanos y Protección Ciudadana del Estado de Baja California. 2003. Recomendación 6/2003.

- $\quad$ Reding, Arturo. 2008. “Movilidad laboral en el Valle de San Quintín, Baja California, 2000-2005". Tesis COLEF.

- Secretaría de Desarrollo Social. 2010. Diagnóstico del Programa de Atención a Jornaleros Agrícolas. México: Secretaría de Desarrollo Social.

- Velasco, Laura., Zlolniski, Christian., Coubès, Marie-Laure. 2014. De jornaleros a colonos: residencia, trabajo e identidad en el Valle de San Quintín. México: El Colegio de la Frontera Norte.

- Weller, Jürgen. 2012. "Vulnerabilidad, exclusión y calidad del empleo: una perspectiva latinoamericana. Realidad, Datos y Espacio". Revista Internacional de Estadística y Geografía. Vol. 3 Núm. 2 mayo-agosto. pp 82-97. 